\title{
COMPARISON OF THE FLUORESCENT POLARIZATION (TDX) AND THE ENZYMATIC COMPETITIVE (EMIT 2000) IMMUNE ASSAYS FOR THE MEASUREMENT OF CYCLOSPORIN A BLOOD CONCENTRATION
}

Elias David-Neto, Carlos A. F.Ballarati, Orlando J. Freitas, Francine C. Lemos, William C. Nahas, Sami Arap and Jorge Kalil

RHCFAP/3025

DAVID-NETO E et al. - Comparison of the fluorescent polarization (TDx) and the enzymatic competitive (EMIT 2000) immune assays for the measurement of cyclosporin A blood concentration. Rev. Hosp. Clín. Fac. Med. S. Paulo 55(6):207-212, 2000.

Evaluation of Cyclosporin A (CyA) blood concentration is imperative in solid organ transplantation in order to achieve maximal immunosuppression with the least side effects.

We compared the results of whole blood concentrations of CyA in 50 blood samples simultaneously evaluated by the fluorescent polarization immune assay (TDx) and the enzymatic competitive immune assay (EMIT 2000).

There was a strong correlation between both kits for any range of $\mathrm{CyA}$ blood concentration $(\mathrm{R}=0.99, \mathrm{p}<0.001)$. The within-run and between-days coefficient of variation were less than $4 \%$ for both assays.

The cost for each CyA measurement was 50\% lower for the EMIT assay when compared to the TDx assay.

We concluded that the EMIT is as accurate as the TDx in measuring CyA blood concentration and has the advantage of a lower cost, as well as the possibility of widespread access to the EMIT methodology in contrast to the TDx equipment, allowing the laboratory to perform several routines within a working day.

DESCRIPTORS: Cyclosporin A. Enzymatic competitive immune assay. Fluorescent polarized immune assay. Renal transplantation. Immunosuppression.

Cyclosporin A (CyA) is a major immunosuppressant used in solid organ transplantation. Its introduction almost two decades ago contributed not only to improvement of the one-year graft survival rate but also to the increased half-life of the transplanted organs.

However, CyA is difficult to handle because of its narrow therapeutic window and its serious side effects. Therefore, CyA blood levels are frequently monitored either by trough levels or by complete or abbreviated area under the time/concentration curve (AUC) ${ }^{1,2}$.

A precise assay for measuring $\mathrm{CyA}$ blood levels is mandatory for any transplant center dealing with this drug. In our center, CyA was previously monitored using the polarized immunofluorescence assay TDx (AbbottTDx, Abbott Laboratories, Illinois, USA).

Although extremely accurate in measuring CyA blood concentrations, the TDx assay has some drawbacks.

From the Kidney and Pancreas Transplant Service Department and the Clinical Laboratory, Hospital Sírio Libanes.
First is that it measures not only the parent drug but is cross-reactive even if it occurs to a lesser extent (9.4\%). Second is that TDx methodology requires blood samples to be collected, stored, and then measured at once, usually once daily, because the TDx apparatus is usually not functioning the whole day in most laboratories. The consequence of this limitation is that dose adjustments usually are done with a 24-hour delay. Third is that TDx technology is not available in most laboratories and fourth is that the cost of each TDx measurement is comparatively high. 
The availability in Brazil of the EMIT 2000 assay (Syva CompanyDade Behring Inc, Cupertino, CA, USA), already in use in other countries ${ }^{3-9}$, warrants a study comparing both assays.

In this study, we have compared the accuracy, costs, easiness, and efficiency of the EMIT 2000 to the TDx assays for the measurement of whole blood levels of CyA in renal transplanted patients.

\section{METHOD}

Blood samples were obtained from the first patients who needed to have CyA blood levels measured at our transplant center. Consecutive patients were enrolled in the study until a total of 50 different blood samples could be collected. Usually at our transplant center, we measure whole blood levels of CyA either at $0,1,2$, and 4 hours, at 2 and 4 hours, or only at 2 hours after the morning oral dose, in order to calculate abbreviated AUC. Therefore, many blood samples were collected from the same patient. Each blood sample was divided into 8 identical EDTA tubes, and was identified and stored at $2-8^{\circ} \mathrm{C}$ for further analysis. All patients were receiving Sandimmun Neoral (Novartis, Basel, Switzerland).

Blood samples were simultaneously analyzed for both assays, TDx (Abbott Laboratories, Illinois, USA) and EMIT 2000 (Syva Company-Dade Behring Inc, Cupertino, CA, USA).

The TDx assay is a fluorescent polarization immunoassay (FPIA) reagent system for the measurement of CyA in whole blood. It uses a competitive binding immunoassay methodology that allows tracer-labeled antigen (CyA) and patient antigen to compete for binding sites on the antibody molecules. The components in this competitive binding reaction are monoclonal antibodies, the patient antigen, and the antigen labeled with fluorescein (tracer-antigen complex). When competitive binding occurs, the more tracer-antigen complex binding to the antibody molecule, the less tracer-antigen complex remains in solution. If the patient sample contains a low concentration of CyA (the patient antigen), after the competitive binding reaction reaches a steady state, there is a high concentration of bound tracer in the reaction mixture and polarization is high. The intensity of polarized light is then measured by the FPIA optical assembler (TDx-FLEX Abbott Laboratories, Illinois, USA).

The EMIT 2000 cyclosporin-specific assay is an enzymatic competitive immune assay using rat monoclonal antibodies that are highly specific for CyA. According to the manufacturer, during the assay, the CyA in whole blood competes with the CyA in the enzymatic reagent $B$ labeled with the enzyme glucose 6-phosphate dehydrogenase (G6PDH). The free enzyme then turns the nicotinamide adenine nucleotide (NAD) into NADH. This promotes a change in the absorbance kinetics that can be measured by spectrometry (Selectra II Bayerâ ).

The calibration curve of each assay requires 6 different $\mathrm{CyA}$ concentrations to be tested: 0, 50, 100, 200, 350, and $500 \mathrm{ng} / \mathrm{ml}$ for the EMIT and 0 , 100, 250, 500, 1000, and $1500 \mathrm{ng} / \mathrm{ml}$ for the TDx. During this study, the calibration curves were checked for 30 consecutive days using low, medium, and high CyA concentration samples and proved to be stable for 30 days in both assays.

For each assay, whole blood concentration of CyA was measured in duplicate (concentration 1 and 2, C1a and $\mathrm{C} 2 \mathrm{a}$ ) to obtain a within-run coefficient of variation ( $\mathrm{CV})$, either for TDx or EMIT. Within-run CV was calculated using the equation: $\mathrm{CV} \%=[100-(\mathrm{C} 1 \mathrm{a} \times 100) / \mathrm{C} 2 \mathrm{a}]$, with all results transformed into positive val- ues. Within-run CV was calculated using the data obtained for the first and second assay; therefore, the number of values in the statistic analysis is twice the number of blood samples.

In order to obtain the between-day $\mathrm{CV}$, the frozen samples were analyzed 3 days later in a second measurement also performed in duplicate $(\mathrm{C} 1 \mathrm{~b}$ and $\mathrm{C} 2 \mathrm{~b})$ ). Between-day $\mathrm{CV}$ was calculated using concentration 1 (C1) of both measurements for each assay, either TDx or EMIT, where CV\% = [100 - (C1a x 100)/C1b] and transformed into positive values.

Since many transplant centers still use the trough levels to monitor CyA blood concentration, we also analyzed the correlation between the two assays when the CyA concentration was within the range of the clinically used trough levels $(100-350 \mathrm{ng} / \mathrm{ml})$.

In the last 2 years, many centers have been monitoring CyA blood levels according to the maximal concentration (Cmax) that is reached 1-2 hours after an oral dose of Sandimmun Neoral ${ }^{\circledR}$. The clinically expected range of these Cmax concentrations is between 700 and $1600 \mathrm{ng} / \mathrm{ml}$. Because of this, we also analyzed the CVs and the correlation between the two assays obtained when CyA blood levels were in the Cmax range.

The analysis of costs was made using the last price for the TDx kit acquired by our institution. The price used for the EMIT 2000 kit was obtained from the Dade-Behring company in Brazil.

Data is presented as mean \pm SD for parametric data and median (25-75\%) for non-parametric data. A paired $t$ test was used to compare CyA blood concentrations between the two assays (TDx vs EMIT). The $t$ test was used to compare within-run and between-day CV. For non-parametric data, a MannWhitney Rank Sum test was used. Simple linear regression was performed between CyA concentrations 
obtained with both assays. The data was analyzed by means of the statistical software SigmaStat 2.0 (Jandel Scientific, San Rafael, CA, USA).

\section{RESULTS}

Fifty blood samples were collected from 9 different renal transplanted patients.

In these 50 samples, the range of CyA concentrations found was in accordance with those used in clinical practice. Mean \pm SD (minimum and maximum range) CyA concentration for the TDx and EMIT assays were $676 \pm 401 \mathrm{ng} / \mathrm{ml}(42-1497 \mathrm{ng} / \mathrm{ml})$ and $695 \pm 450 \mathrm{ng} / \mathrm{ml}(38-1635 \mathrm{ng} / \mathrm{ml})$, respectively $(\mathrm{p}=\mathrm{NS})$. There was an extremely good correlation between the two assays as illustrated in figure 1 ( $\mathrm{R}=0.99, \mathrm{p}<0.001)$.

Table 1 summarizes between-day and within-run CVs obtained in the 100 samples. There were no significant differences in either of these CVs. In the CyA blood levels ranging between 100 and $350 \mathrm{ng} / \mathrm{ml}$, a higher CVs was observed, but it was still not statistically significant.

Twenty measurements were within the trough level range. The mean concentration (range) for these 20 samples for TDx and EMIT was $260 \pm 56 \mathrm{ng} /$ $\mathrm{ml}(144-345)$ and $227 \pm 63 \mathrm{ng} / \mathrm{ml}$ $(122-328)(\mathrm{p}=0.10)$, respectively. The median (25-75\%) within-run $\mathrm{CV}$ was $2.9 \%(1.5-4.2 \%)$ for TDx when compared to $2.8 \%(2.1-4.3 \%)$ for EMIT ( $\mathrm{p}=\mathrm{NS})$. The mean between-day CV was $3.7 \pm 2.4 \%$ for TDx and $4.4 \pm$ $4.2 \%(\mathrm{p}=\mathrm{NS})$ for EMIT $(\mathrm{p}=\mathrm{NS})$. For this range of trough levels, the correlation between the concentrations obtained using both assays was also excellent $(\mathrm{R}=0.97, \mathrm{p}<0.001)$ ), as seen in figure 2 .

Forty-eight CyA measurements were within the clinically expected Cmax concentration. Mean CyA blood levels for these 48 measurements was $1045 \pm 261 \mathrm{ng} / \mathrm{ml}$ (720-1572) for the TDx assay and 1100+264 (755-1598) for the EMIT assay $(\mathrm{p}=\mathrm{ns})$. There was a very good correlation between these two assays in the blood concentrations measured ( $\mathrm{R}=0.98, \mathrm{p}<0.001)$ (Fig. 3). The mean within-run $\mathrm{CV}$ was $1.9 \pm 2.0 \%$ for TDx and $1.7 \pm 0.9$ for the EMIT ( $\mathrm{p}=\mathrm{NS}$ ). The mean between-day
$\mathrm{CV}$ was $1.8 \pm 1.7 \%$ for TDx and $1.3 \pm 0.9$ for the EMIT $(\mathrm{p}=\mathrm{NS})$.

CyA measurement using the EMIT 2000 is less time-consuming than the TDx assay (16 vs 25 minutes). Also, the blood volume required is $100 \mathrm{ul}$ vs150 ul for EMIT-2000 and TDx, respectively.

Each EMIT 2000 kit costs US\$970.00 for 100 tests, while the TDx

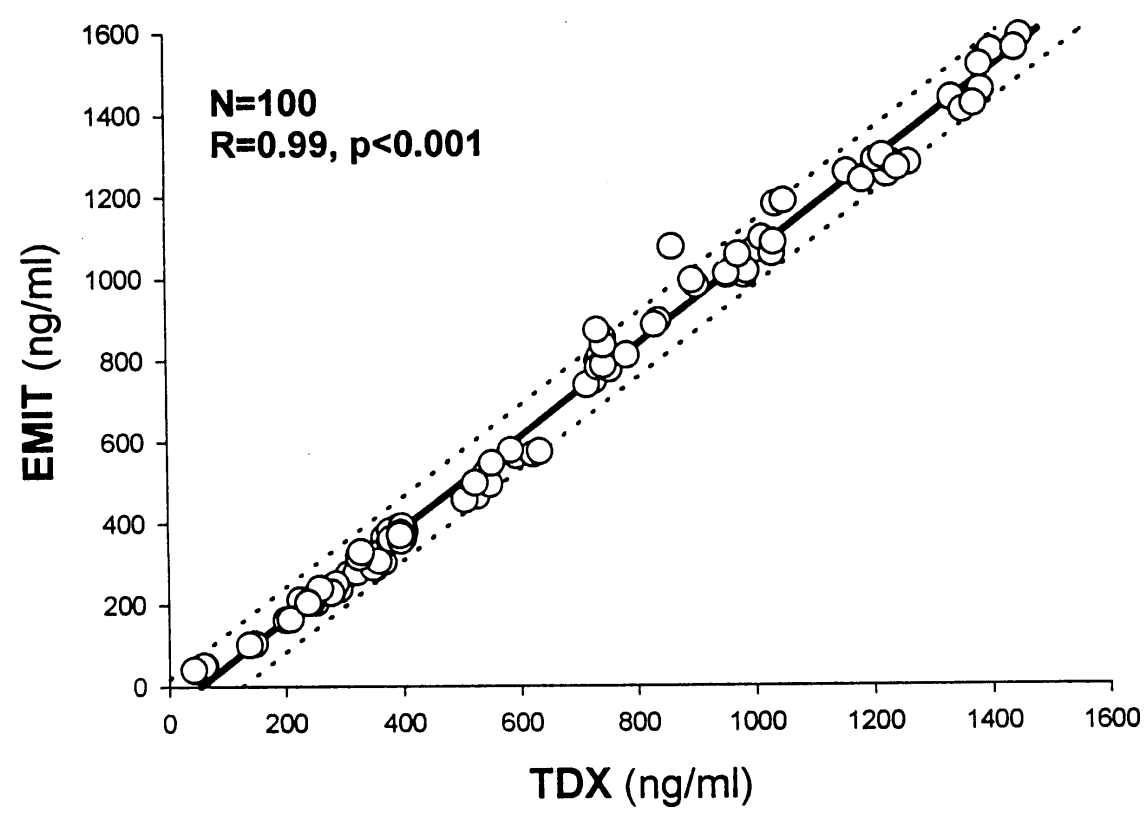

Figure 1 - Correlation between CyA whole blood levels measured by the EMIT 2000 and TDx assays.

Table 1 - Coefficients of variation of fluorescent polarization immunoassay (TDx) and enzymatic competitive immune assay (EMIT) in the most used CyA blood concentration ranges in clinical practice.

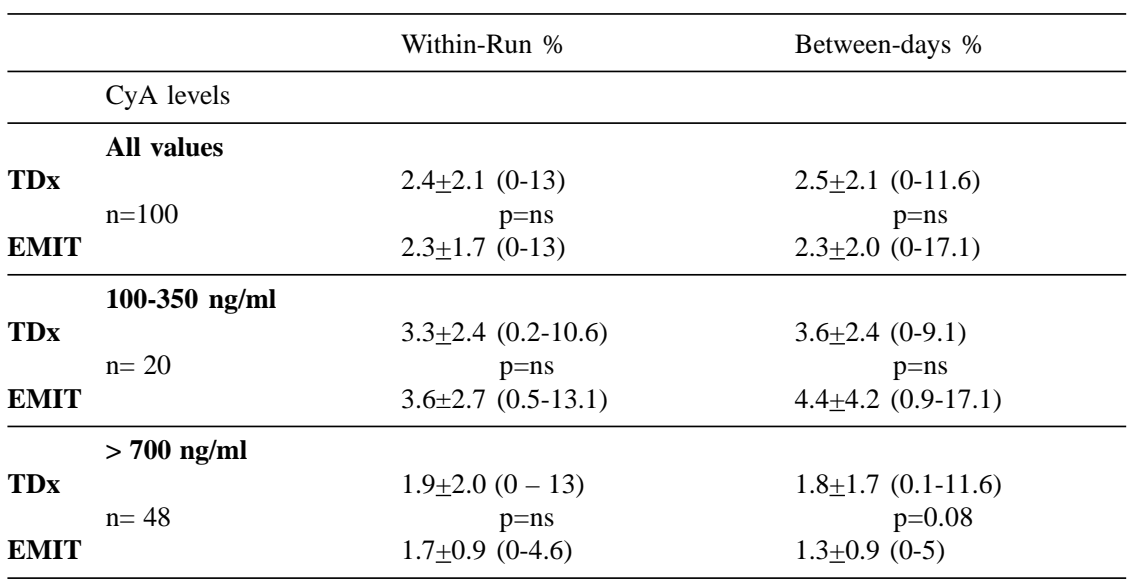

Mean \pm SD (Range), ns: not statistically significant. 


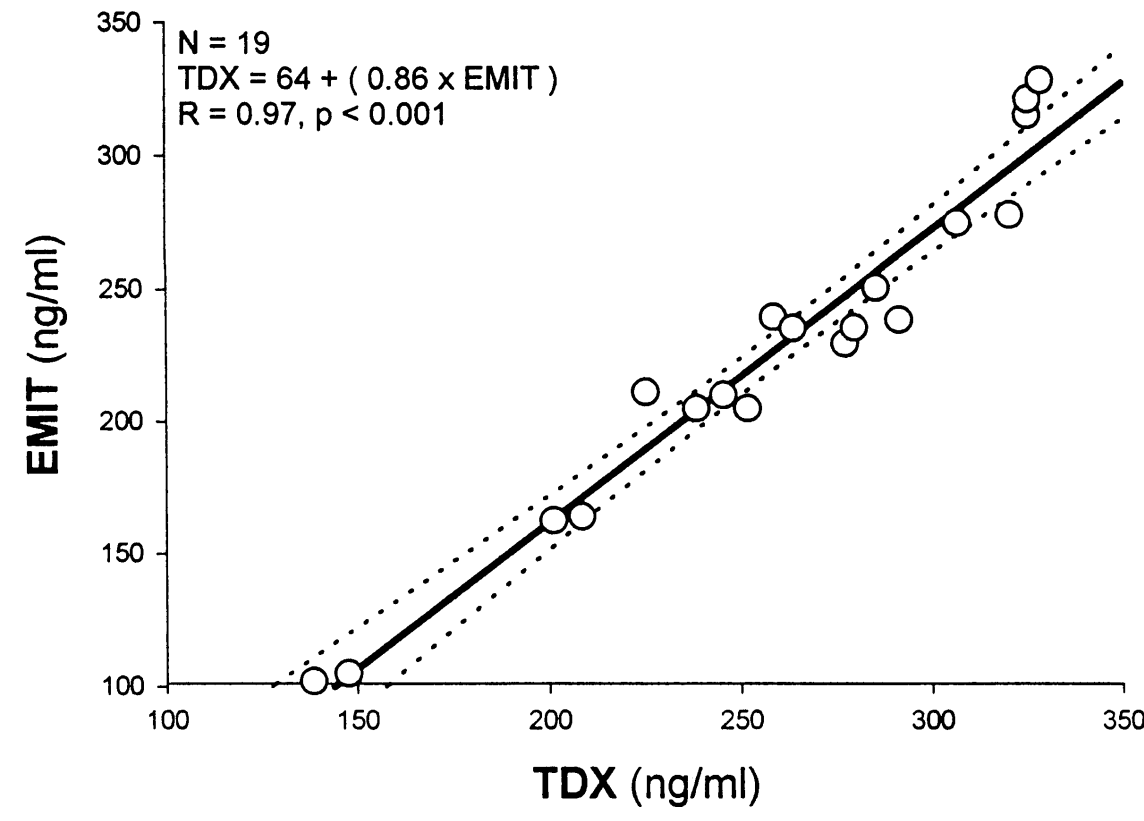

Figure 2 - Correlation between CyA blood levels in the range of trough concentration (Cmin).

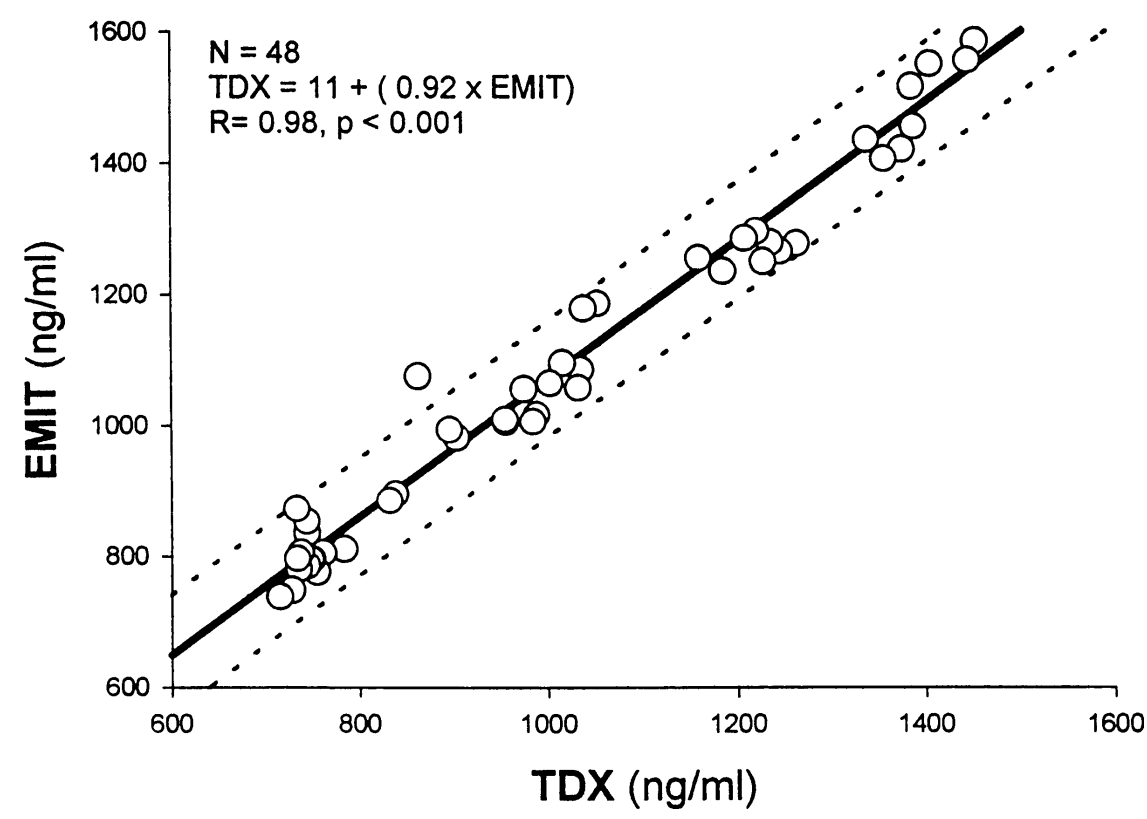

Figure 3 - Correlation between CyA whole blood levels for the range of maximal concentration (Cmax).

kit for the same number of tests costs US $\$ 2,023.00$. Therefore, the cost per test is US\$9.70 for the EMIT 2000 and US $\$ 20.20$ for the TDx assay. Although the cost of calibrators (quantity sufficient for 6 months) is US $\$ 808.50$ for the EMIT 2000 and US\$367.14 for the TDx-Abbott, we decided not to take concentration by the EMIT 2000 assay is as accurate as measurement by the TDx assay in renal transplanted patients.

There was a strong correlation $(\mathrm{R}=0.99)$ between samples measured simultaneously by both assays (Fig. 1). Even when we filtered for samples with high levels, the correlation was almost perfect (0.97). For the CyA range of currently used trough levels, the correlation was also very good $(\mathrm{R}=0.98)$. However, CyA levels measured by the EMIT 2000 assay tend to be lower (approximately $50 \mathrm{ng} / \mathrm{ml}$ ) in the established range of Cmin. Nevertheless, this variation does not affect clinical practice.

This high level of correlation between the EMIT assay and other assays has already been shown in other studies $^{9,10,11}$.

The analysis of the within-run and between-day CVs showed a very low variation for both assays either for high or low CyA blood concentrations. In fact, as seen in table 1, both CVs were below $4 \%$ for both assays. This low $\mathrm{CV}$ is extremely important for dose adjustment, since any increase or decrease in CyA blood concentration higher than $4 \%$ is certainly not attributable to measurements errors.

CyA is broken into many metabolites, some with immunosuppressive and toxic properties. Because of this, a consensus conference in 1995 declared that the best assay for CyA blood analysis is one that specifically measures the parental drug concentration only ${ }^{12}$. Although in this study we have not analyzed the cross-reactivity of the parent drug and the CyA metabolites in either assay, data showing that the EMIT 2000 assay is more specific for the parent drug CyA than the monoclonal fluorescent polarization immunoassay TDx, when HPLC is used as the gold standard method, have been published ${ }^{10,11}$. Also, the EMIT 2000 assay does not cross-react with 
other immunosuppressant drugs, such as mycophenolate acid, and has less than $4.6 \%$ cross-reactivity with sirolimus.

Currently, the evaluation of CyA blood concentration is becoming increasingly necessary in order to monitor the drug therapeutic level and avoid CyA toxicity. For example, it has been suggested that a maximal concentration of CyA (Cmax) of 1200 to $1700 \mathrm{ng} / \mathrm{ml}$ has to be achieved within the first 5 days after renal transplantation in order to minimize the incidence of rejection. To achieve this, it is necessary to monitor Cmax almost after each oral dose and make the dose adjustments before the next dose. This fine tuning can only be achieved by using an assay that can be performed any time during the day and with the results obtained before the next dose.

One of the major advantages of the EMIT 2000 over the TDx, in our opinion, is the fact that the EMIT 2000 assay allows the CyA blood concentration to be measured any time during the day and not only once or twice daily as occurs with the TDx assay. Frequent daily analyses are possible because, once calibrated, the
SELECTRA II-Italab system is able to analyze CyA concentration without interrupting the other laboratory routines. On the other hand, with the TDx technology, the laboratory has to keep the TDx-FLEX turned on during the whole day in order to measure few CyA samples. Usually, laboratories turn the TDx-FLEX on, only once a day.

Another aspect of this benefit is that it extends the possibility of measuring CyA to any laboratory lacking the TDx technology, which is a great advantage for the many small transplant centers in Brazil.

The major disadvantage of the EMIT 2000 assay is that measuring CyA concentrations over $500 \mathrm{ng} / \mathrm{ml}$ requires a dilution of blood samples. This requirement is particularly important because CyA maximal concentration (usually higher than $500 \mathrm{ng} / \mathrm{ml}$ ) is the parameter used to monitor immunosuppression. It was a surprise then that the $\mathrm{CV}$ obtained in the high concentration range (> $700 \mathrm{ng} / \mathrm{ml}$ ) had such a low variation as shown in table 1 .

The other benefit of the EMIT 2000 assay is the lower cost when compared to the TDx. Each CyA measurement costs less than half the price of the TDx measurement. The analysis of costs did not take into account the calibration kit costs. Since the calibration curve is stable for 1 month in both assays and, for each calibrator kit, there are enough reagents for a period of 6 months, calibration costs are minimal when the laboratory performs a large number of measurements in a 6-month period. Reducing medical costs is currently mandatory, particularly with an expensive drug like CyA that needs frequent monitoring.

In summary, we have shown that the EMIT 2000 assay for the CyA blood concentration is an accurate assay when compared to the TDx assay. It has also advantages when compared with the TDx, which include lower cost and more accuracy with respect to the intact drug and the fact that the laboratories can perform many routines within a day.

\section{ACKNOWLEDGEMENTS}

This study was partially supported by the Dade-Behring - Brazil.
DAVID-NETO E e col. - Comparação dos imuno-ensaios de fluorescência polarizada (TDx) e enzimático competitivo (EMIT 2000 ) na dosagem da concentração de ciclosporina A no sangue total.

Rev. Hosp. Clín. Fac. Med. S. Paulo 55(6):207-212, 2000.

A avaliação da concentração sanguínea de ciclosporina A (CyA) é necessária em transplantes de órgãos sólidos para obter-se máxima imunosupressão e mínimos efeitos colaterais.

Nós comparamos os resultados da concentração de CyA em 50 amostras sanguíneas analisadas pelos métodos dos imuno-ensaios de fluorescência polarizada (TDx) e enzimático competitivo (EMIT 2000).

Houve uma forte correlação entre ambos métodos para qualquer faixa de concentração de CyA ( $R=0.99$, $\mathrm{p}<0.001)$. Os coeficientes de variação intra e interensaio foram menores que $4 \%$ para ambos os métodos.

O custo para cada análise de CyA foi $50 \%$ menor para o EMIT em comparação com o TDx.
Concluímos que a metodologia EMIT é tão acurada quanto a de TDx para dosar CyA em amostras sanguíneas. Além disso, a metodologia EMIT é mais prática para ser realizada e mais barata, sendo ainda possível adotá-la para dosagens de CyA em vários horários de um mesmo dia.

DESCRITORES: Ciclosporina A. Imuno ensaio de fluorescência polarizada. Ensaio imuno enzimático competitivo. Transplante renal. Imunossupressão. 


\section{REFERENCES}

1. IANHEZ LE, CHOCAIR PR, FONSECA JA et al. - Cyclosporin A: experience of the Renal Transplant Unit of the Clinical Hospital of the Medical College of the University of Sao Paulo. Rev Assoc Med Bras 1991; 37 (2): 67-72.

2. DAVID-NETO E, LEMOS FB, FURUSAWA EA et al. - Impact of cyclosporin A pharmacokinetics on the presence of side effects in pediatric renal transplantation. J Am Soc Nephrol 2000; 11 (2): 343-349.

3. DIAS VC, LEGATT DF \& YATSCOFF RW - The EMIT cyclosporine assay: development of application protocols for the Boehringer Mannheim Hitachi 911 and 917 analyzers. Clin Biochem 1997; 30 (2): 155-162.

4. SALLUSTIO BC, MORRIS RG, SACCOIA NC et al. - Reducing the cost of cyclosporin assays: modification of the EMIT 2000 method. Ther Drug Monit 1997; 19 (2): 208-211.

5. SCHUTZ E, SVINAROV D, SHIPKOVA M et al. - Cyclosporin whole blood immunoassays (AxSYM, CEDIA, and Emit): a critical overview of performance characteristics and comparison with HPLC. Clin Chem 1998; 44 (10): 2158-2164.

6. STEIMER W - Evaluation of the AxSYM CyA assay compared with HPLC, TDx monoclonal and EMIT with both pretreatments. Transplant Proc 1998; 30 (8): 4045-4047.
7. STEIMER W - Performance and specificity of monoclonal immunoassays for cyclosporine monitoring: how specific is specific? Clin Chem 1999; 45 (3): 371-381.

8. WALLEMACQ PE \& ALEXANDRE K - Evaluation of the new AxSYM cyclosporine assay: comparison with TDx monoclonal whole blood and Emit cyclosporine assays. Clin Chem 1999; 45 (3): 432-435.

9. HAMWI A, VEITL M, MANNER G et al. - Evaluation of four automated methods for determination of whole blood cyclosporine concentrations. Am J Clin Pathol 1999; 112 (3): 358-365.

10. ARMIJO JA \& DE COS MA - Parent cyclosporine in whole blood by FPIA and EMIT after kidney, heart, and liver transplantation. Clin Biochem 1994; 27 (6): 498-501.

11. DUSCI LJ, HACKETT LP, CHISWELL GM et al. - Comparison of cyclosporine measurement in whole blood by high-performance liquid chromatography, monoclonal fluorescence polarization immunoassay, and monoclonal enzyme-multiplied immunoassay. Ther Drug Monit 1992; 14 (4): 327-332.

12. OELLERICH M, ARMSTRONG VW, KAHAN B et al. - Lake Louise Consensus Conference on cyclosporin monitoring in organ transplantation: report of the consensus panel. Ther Drug Monit 1995; 17 (6): 642-654. 